This is the peer reviewed version of the following article: Hearman, V. (2018), Screening East Timorese Women and History in Timor-Leste's Beatriz's War. Gender \& History, 30: 786-802, which has been published in final form at https://doi.org/10.1111/1468-0424.12380. This article may be used for non-commercial purposes in accordance with Wiley Terms and Conditions for Use of Self-Archived Versions. This article may not be enhanced, enriched or otherwise transformed into a derivative work, without express permission from Wiley or by statutory rights under applicable legislation. Copyright notices must not be removed, obscured or modified. The article must be linked to Wiley's version of record on Wiley Online Library and any embedding, framing or otherwise making available the article or pages thereof by third parties from platforms, services and websites other than Wiley Online Library must be prohibited.

\title{
Screening East Timorese women and history in Timor-Leste's Beatriz's War
}

Timor-Leste's first feature film, A Guerra da Beatriz (Beatriz's War) depicts the lives of a group of girls and women, survivors of a village massacre, during the Indonesian occupation of what was then known as East Timor. ${ }^{1}$ Beatriz's War, a political melodrama, focuses on women's resistance to Indonesian rule. The film recasts the meanings of resistance, particularly examining how it occurs at an everyday level and then rendered invisible by categories such as hero, traitor and victim over the course of a long struggle for self-determination. The film also plays an important role in contributing to a visual history of the new nation of Timor-Leste.

After being colonised by Portugal, then by Indonesia for twenty-four years (1975-1999), East Timor reverted to United Nations (UN) administration following a historic ballot on Indonesian rule, sponsored by the world body. East Timor became independent in 2002, and is known today as Timor-Leste, with a 2015 population of 1.18 million. ${ }^{2}$ As with many postcolonial societies, historical accounts about East Timor have predominantly focused on resistance, heroism, victimhood and suffering. However, the everyday, grounded experiences of survival by ordinary Timorese, in the face of a violence that has seeped into the fabric of life, have by and large remained missing from the country's history, as Lia Kent has argued. ${ }^{3}$ In this article, I 
examine how Beatriz's War contributes to visual representations of the occupation on one hand, and on the other, those everyday experiences of violence and responses to it.

The historiography of Timor-Leste has primarily focused on the documentation and analysis of the Indonesian occupation. ${ }^{4}$ Despite being relatively brief in comparison to some 400 years of Portuguese administration, the Indonesian occupation heralded the most drastic change to the territory with its aggressive attempt of Indonesianising East Timor through policies in areas such as language, education and spatial and family planning. Between 1975 and 1999, an estimated 100,000 or about one-sixth of East Timor's population died from famine, war and violence. ${ }^{5}$ The Indonesian state relied on frequent, demonstrative and brutal violence to maintain the occupation. As such, Beatriz's War focuses on the lives of the survivors of one army-led massacre in Krarás, Viqueque District in 1983.

The film is a part of recent efforts to inscribe women and their experiences during the Indonesian occupation into the national narrative of this new nation. ${ }^{6}$ The East Timor Reception, Truth and Reconciliation Commission, (Comissão de Acolhimento, Verdade e Reconciliação, East Timor, CAVR) which derived its mandate from the UN administration of the territory, collected hundreds of testimonies from women about their experiences during the occupation. But such accounts could not possibly represent the experiences of all Timorese women in all their nuanced complexities. Recent efforts at inserting women into the national narrative have focused on highlighting their roles as armed combatants and as those assisting the guerrillas, partly as a result of the Timorese government's focus on the wellbeing of the mainly male resistance veterans and their provision of a pension for the veterans. ${ }^{7}$ Yet the film suggests that women's actions (as were men's) during the 
occupation were far more complex than simply as heroic combatants and active supporters of the resistance or passive victims.

\section{Beatriz's War as history film and political melodrama}

Firstly, however, it is pertinent to discuss the role and capacity of the history film in providing new ways for audiences to access the past, particularly in the visual and aural senses. Historians agree of the power of film as a medium and the film history's capacity to provide 'a cultural access point' to millions of people. ${ }^{8}$ I apply the concepts that Robert Rosenstone and Hayden White have put forward, that history films engage in their own kind of history-making, and that the visual images and sound that the history film brings together constitute its own contribution to the history of a particular place, people or event. ${ }^{9}$ White refers to this practice as historiophoty, "the representation of history and our thought about it in visual images and filmic discourse." ${ }^{10} \mathrm{He}$ argues that with the nature of historical evidence being as much visual, as oral and written, and our communicative conventions and modes being as much pictorial as verbal, historians cannot be focused primarily on the written word. In fact, he goes further by pointing out that cinema and video are better than the written word at representing certain phenomena, including landscape, scenery, atmosphere, emotions, and complex events like war and battles. In keeping with this, I explore how this particular film 'makes history,' in a manner that is in keeping with its visual and filmic nature.

In terms of genre, we can characterise Beatriz's War as a political melodrama. The centrality of women's experience in melodrama makes the genre a site for the manifestation of social restraint and patriarchal control over women's lives. The genre also provides possibilities for demonstrating how such control could be overcome. As 
such, the category of melodrama becomes particularly suitable in describing Beatriz's War, as will become evident. The film displays many of the qualities Peter Brooks associates with the melodrama, such as 'strong emotionalism, moral polarization and strong schematization; extreme states of being, situations, action; overt villainy, persecution of the good, and final reward of virtue. ${ }^{11}$ Elaborating further on the melodrama, Nick Browne argues, however, that in non-Western contexts, the concept of 'political melodrama', the inclusion of the factor of social conditions, is more apt. He writes, "In this way, we might treat "melodrama" as an expression of a mode of injustice whose mise-en-scene is precisely the nexus between public and private life, a mode in which gender as a mark of difference is a limited, mobile term activated by distinctive social powers and historical circumstances. ${ }^{12}$ In the political melodrama, the action is situated in the context of a certain historiography, 'a series of dates that organize the entire film and put this melodramatic form in relation to the audience's popular memory of contemporary history. ${ }^{13}$ For Beatriz's War, this historiography relates to events during the Indonesian occupation, such as the invasion of East Timor in December 1975, the Krarás massacre of 1983 and the UN-sponsored ballot of 1999.

Several scholars have analysed Beatriz's War, the events it depicts and its role in the new nation's attempts to grapple with past history. In a conventional approach to history films, historian Clinton Fernandes provides a comparison between different stages of East Timorese history depicted in the film and real-life events and personalities in the independence struggle. ${ }^{14}$ Cultural studies scholar, David Callahan argues the film has contributed to the construction of a collective memory of a specific traumatic historical event. The film, in his view, explores what processes may 
be appropriate in the present to deal with 'a collectively traumatic past', including a collective storytelling that the film itself contributes to. ${ }^{15}$

In the next sections of the article, I provide a historical background and a brief discussion of how the Indonesian occupation has been depicted on film. I then go on to discuss the contents of Beatriz's War and its contribution to a historiophoty of the occupation and to more complex narratives about women's experiences. Finally, I examine some criticisms levelled against the film by Indonesian and Timorese film commentators and activists in order to discuss some of the critical responses to it as a history film. In so doing, I investigate the film's 'rules of engagement' with history, to borrow Rosenstone's term, as well as its contribution to the historiophoty of East Timor/Timor-Leste.

\section{Historical background}

Some discussion of the background events is necessary at this point. The Portuguese government began the process of divesting itself of its colonial possessions in Asia and Africa, including Timor-Leste, in the aftermath of its 1974 Carnation Revolution and the resumption of democratic rule in Portugal. During the decolonisation process, Timorese political parties developed, as did differences between them regarding the most desirable political solution for the territory. The most prominent of these new parties was Fretilin (Frente Revolucionaria do Timor Leste Independente, East Timor Revolutionary Front for Independence). Fretilin was a leftist nationalist party led by activists such as Nicolau Lobato, José Ramos Horta and Mari Alkatiri, which argued for independence from Portugal to occur as soon as possible. They were inspired by Marxist ideas, the democratic revolution in Portugal, and national liberation movements in the developing world, particularly those in Lusophone Africa. ${ }^{16}$ The 
more conservative Timorese Democratic Union (União Democrática Timorense, UDT) preferred a longer transition period to independence from colonial rule. ${ }^{17}$

A civil war between the two parties broke out in August 1975. The Portuguese governor, Lemos Pires fled Dili, the capital, for nearby Atauro Island, thus leaving a political vacuum. Fretilin defeated UDT in the civil war and declared independence from Portugal on 28 November 1975. Some UDT leaders aligned themselves with Indonesia, which controlled the western half of Timor Island. After several months of carrying out destabilisation campaigns against East Timor, Indonesia under Suharto's authoritarian New Order regime invaded on 7 December 1975. Beatriz's War begins by depicting village life just prior to the invasion, and traces the lives of the key protagonists: Beatriz Martins, her husband, Tomás dos Anjos, and her sister in law (and Tomás' sister), Teresa.

Following the invasion, populations fled to the mountains to avoid Indonesian troops and to gain the protection of Fretilin's armed forces, Falintil (Forças Armadas de Defesa de Timor-Leste, Armed Forces for the Defence of Timor-Leste). Despite forcible Indonesian 'integration' of East Timor in July 1976 as its twenty-seventh province, over the next several years, though with increasing difficulty, Fretilin designated refuge areas in the mountains as liberated zones (zonas libertadas). There, the displaced population survived together. In these zones, Fretilin continued popular education and literacy programs it had established prior to the invasion. The Falintil resistance had suffered great losses by late 1978. It was no match for Indonesian military might, particularly after the introduction of aerial bombardment that was made possible by Western military assistance to Indonesia.

As Falintil forces found it harder and harder to defend and feed large groups of people and needed to be constantly on the move, civilians, including in this case, 
the film's three protagonists surrendered to the Indonesian army. The Indonesian army placed these civilians in holding camps or 'new villages,' to deter them from supporting the Timorese resistance. The army moved villagers from Krarás in Viqueque District, for example, to an area called Bibileo in the same district. War and displacement disrupted food cultivation and famine ensued.

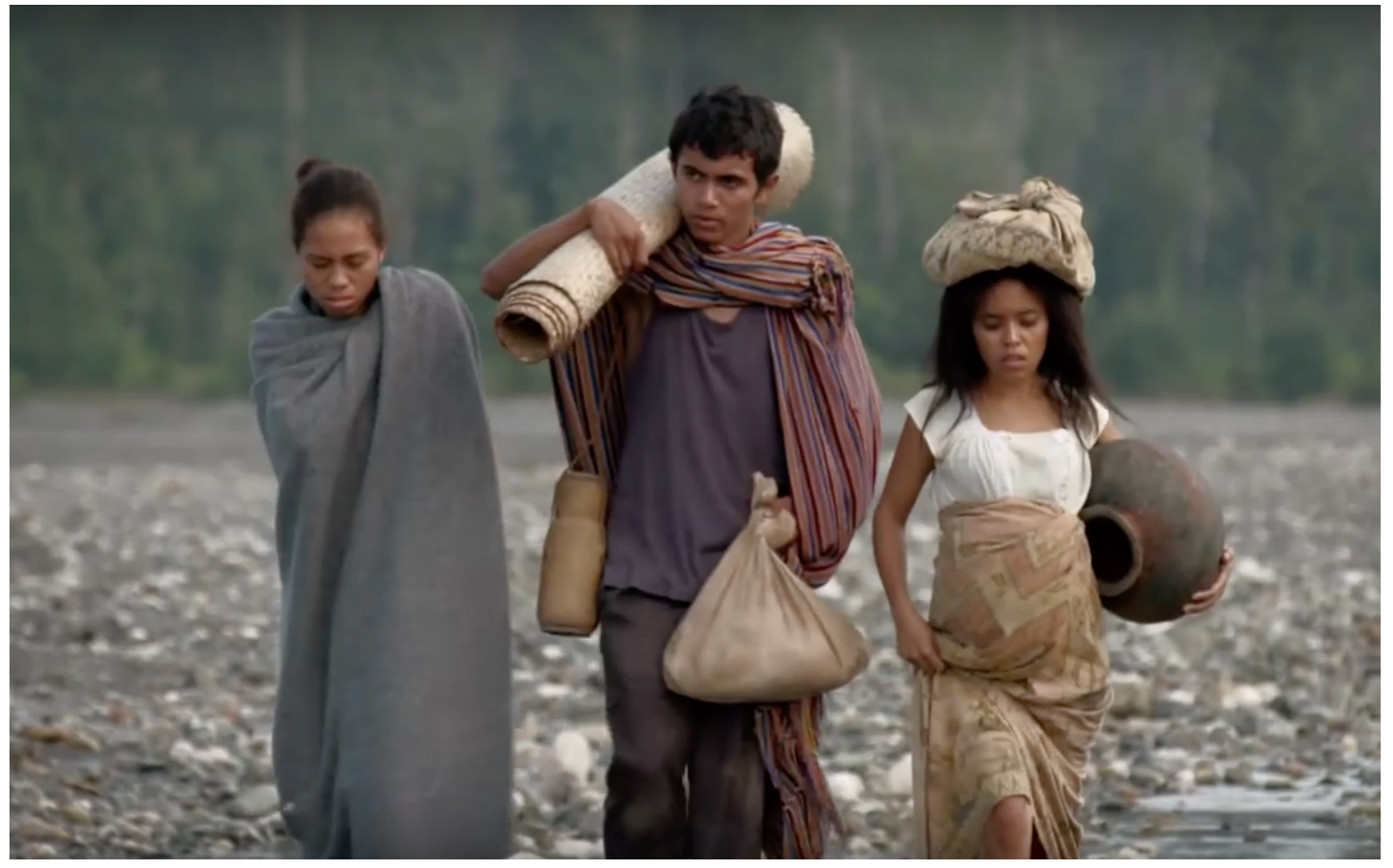

Image 1: Teresa, Tomas and Beatriz surrender to Indonesian forces. From Beatriz's War, dir. Bety Reis and Luigi Acquisto. Screengrab.

Indonesia consolidated its rule over the province in the following few years, to the extent that in 1983, the Timorese resistance fighters and the Indonesian army agreed to a brief ceasefire from April to July. In August, a group of Timorese working as Indonesian army auxiliaries killed fourteen army engineers in Viqueque District, as part of an uprising, a levantamento, organised by the resistance. ${ }^{18}$ In retaliation, the Indonesian army undertook several weeks of counter-insurgency operations that 
resulted in hundreds of civilians killed. The worst atrocity was the shooting on 17 September, at a riverbed in Tahubein, of 141 men and boys from Bibileo, who had fled to Buikarin to escape the operations. Beatriz's War depicts the lives of the women who survived this massacre, who were then relocated to yet another village, Klalerek Mutin.

In the 1999 referendum, $78.5 \%$ of Timorese in East Timor and those in the diaspora voted against remaining with Indonesia. An emergency intervention, the International Forces for East Timor (InterFET) consisting of Australian and New Zealand troops, landed in September 1999 to stop the violence by the Indonesian army and its militias following the ballot result announcement. Approximately 2000 people were killed in 1999. Buildings and infrastructure were damaged and destroyed. Following Indonesia's withdrawal, the UN administered the territory until May 2002, when it became the Democratic Republic of Timor-Leste. These historical milestones are marked out in the film.

The CAVR recorded 853 testimonies of gender-based and sexual violence against Timorese women under Indonesian rule, a figure that is bound to represent only a small percentage of the total number of cases. ${ }^{19}$ The testimonies revealed that women were killed, sexually abused, raped, tortured and subjected to coercive sexual relations because of their suspected involvement in the struggle. Women who bore children from rape brought them up in their family environment, usually without support from the Indonesian fathers. Kent has suggested that there was a systematic Indonesian strategy of targeting Timorese elite families to break their capacity to resist, including through the sexual assault of women and the forced removal of children to Indonesia. ${ }^{20}$ 
Women's experiences as victims during the occupation are often narrated by others, such as human rights workers and activists, through a human rights trope. ${ }^{21}$ The frequency with which women's suffering in East Timor is depicted through this trope can, however, also downplay women's agency. A small number of Timorese women activists who were raped and murdered by Indonesian soldiers are celebrated as heroines of the struggle in East Timor, the most prominent of whom are Rosa 'Muki' Bonaparte and Maria Gorete. The focus on these women paradoxically threatens to marginalise women's everyday experiences even further. The mass of women who survived Indonesian rule could not possibly approximate the stature of Bonaparte and Gorete, whose stories, honed over two decades, are recounted as part of the independence struggle's narrative.

The self-determination struggle takes centre stage in Timor-Leste's efforts to construct its national history narratives, including through film and audiovisual representations. The self-determination movement is conventionally depicted as consisting of three fronts, namely the resistance consisting of a small group of armed guerrillas, mostly men; a clandestine section, primarily being made up of young people and women who were based in the urban areas of East Timor and Indonesia; and the diplomatic front located in other countries. Hannah Loney argues, however, that this characterisation of the Timorese self-determination movement as consisting of three pillars is unable to capture women's motivations and specific contributions to the struggle..$^{22}$ Loney, as well as Kent and Nuno Rodrigues Tchailoro have all questioned the extent to which everyday, popular forms of resistance could be accommodated in Timorese national history. ${ }^{23}$ Armed conflict was, after all, only ever a small part of the resistance to Indonesian rule. 
In focusing on women as the main protagonists, Beatriz's War tries to fill this gap, firstly, by providing a nuanced examination of a group of women's lives on an everyday level. The film shows that, over the course of the occupation, women were simultaneously victims, supporters of the Timorese armed resistance, as well as those who kept hope alive by nourishing and fostering a community. In so doing, it raises the notions that survival could entail what might, at first, seem like cooperation and collaboration with the enemy. Therefore, resistance itself can become a source of internal friction, moral discomfort and compromise. These themes will be discussed further below in an exploration of the film. Secondly, the film also contributes to a historicising of the Indonesian occupation and of Timorese culture in visual images and in a filmic medium. So many aspects of everyday life in Timor-Leste in the 1980s and 90s remain visually undocumented, including its rituals and landscapes.

\section{Representing East Timor on screen before and after independence}

During the Indonesian occupation, there was one cinema in Dili, the provincial capital. Those who had a television could watch broadcasts by Television of the Republic of Indonesia (TVRI, Televisi Republik Indonesia), a state monopoly. It was only in 1987 that the Indonesian government issued the first commercial televion licence, preceded by changes in technology, such as the advent of videos and dish receivers. ${ }^{24}$ But only one feature film was ever made on East Timor. In 1991, the state-run National Film Company (Perusahaan Film Nasional, PFN) made Langit Kembali Biru (The Sky Returns to Blue). The film depicts two lovers divided by the conflict, with pro-independence Manuel (Rian Hidayat) on one side, and Ana (Sonia Carrascalão) whose family supported integration with Indonesia, on the other. ${ }^{25}$ Despite the New Order regime's propensity to make historical feature films that 
promoted its perspective on the past, Langit Kembali Biru remains the sole dramatic Indonesian feature film set in East Timor.

Outside Indonesia, films and television documentaries during the occupation depicted East Timor through a human rights trope and aimed to galvanise support for the independence struggle. These included John Pilger's Death of a Nation and Max Stahl's Cold Blood, the latter documenting the 1991 Santa Cruz Massacre, in which the army killed approximately 271 Timorese at a Dili cemetery after a funeral procession. ${ }^{26}$ The focus on Indonesia's human rights abuses continued into the UN administration and beyond, as a result of the 1999 post-ballot violence and lack of accountability by Indonesia for this violence. ${ }^{27}$

Nonetheless, liberation from Indonesian rule has created new opportunities for Timorese filmmakers in terms of subject matter, participants and collaborations. Dili Film Works, an audio-visual production company, was founded in 2010 by emerging Timorese filmmakers Bety Reis, José da Costa, and Gaspar Sarmento. DFW went on to make Beatriz's War in collaboration with Australian filmmakers Luigi Acquisto and Stella Zammataro from Fair Trade Films. The script is co-written by Acquisto and lead actor, Irim Tolentino. Reis and Acquisto co-direct the film. Zammataro and Australian-East Timorese solidarity activist, Lurdes Pires, produce the film, with José da Costa and Nicholas Calpakdjian co-producing. ${ }^{28}$ The Timorese filmmakers met through working on the 2009 Australian film Balibo, set in East Timor. ${ }^{29}$ Tolentino and Reis had acted in the theatre group, Bibi Bulak before respectively taking up the roles of organising extras and assisting with casting on Balibo. Da Costa had acted in the joint Canadian-Australia television miniseries, Answered by Fire (2006) on the 1999 UN referendum, and was a supporting actor on Balibo. Beatriz's War involved Timorese actors and a predominantly Timorese crew. The film's Timorese co- 
director, Bety Reis; co-producer, José Da Costa, and co-scriptwriter, Irim Tolentino all act in Beatriz's War.

The film's modest budget of $\$ 40,000$ was raised through donations, grants and crowdfunding over several years. The Global Film Initiative, a US-based non-profit granting program, provided $\$ 10,000$ in 2011 towards the making of the film. The Timorese government contributed $\$ 5000$ to its production. Several corporations and the Timorese Defence Force provided in-kind contributions.

\section{Historical reconstruction and women's role in history in Beatriz's War}

The film was shot around the capital Dili, the nearby beachside town of Liquiça, the mountainous district of Ainaro, and the villages around Krarás. In its opening scene, on the eve of the Indonesian invasion, Estela (played by co-director, Bety Reis) trudges along a mountain ridge in a heavily misted landscape, guiding a brown Timorese pony. Astride the pony is her eleven-year-old daughter Beatriz, who is soon to be married to a timid boy named Tomás dos Anjos. With Estela now a widow, the arranged marriage is part of her attempt to join her family to that of the powerful Dos Anjos family. Sitting on the ground and using grains of corn to represent value, she and Celestino, Tomás' father, negotiate the amounts of farm animals, traditional textiles (tais) and jewellery for each side to seal the union, in a practice called barlake. ${ }^{30}$ The negotiation scene shows how marriage binds Timorese families together, through the arrival of a new family member into the household that is in turn underpinned by a system of exchange.

On the other side, is the modernising intent of a Catholic priest, Father Nicolau (Osme Gonçalves) who refuses to consecrate the two children's under-age marriage. In 1975, the Popular Timorese Women's Organisation (Organizacão 
Popular Mulheres Timor, OPMT), affiliated to Fretilin, criticised barlake as demeaning to women. ${ }^{31}$ However, the film places barlake within a historical and cultural context, as well as suggesting that resistance to Indonesian rule was strengthened by a social fabric made up of a system of exchange and a network of family connections.

In East Timor, the family unit, part of a larger clan, could function at times beyond the reach of the Indonesian army and state and provided a place for transmitting political beliefs and maintaining cultural practices. Clans became strong bases for resistance against Indonesian rule as clan members defended and assisted one another. This kinship system and inter-clan cooperation created a strong network. It was also in order to disrupt this kinship system that the Indonesian army targeted Timorese women for violence, because they were childbearers and carriers of family honour. ${ }^{32}$

After the invasion, the three youths, Beatriz, Tomás and Teresa, escape to the mountains. The liberated zone provides a peaceful respite and a space in which gender role reversals are possible. Tomás prefers to work with the women collecting wood and cleaning vegetables for the camp's meal, while women like Teresa and Beatriz dress in army fatigues and clean firearms. This portrayal of Tomás's refusal to take part in combat shows his character as timid and averse to confrontations, thereby laying the groundwork for later events in the film. Such a depiction, however, also reflects Fretilin's attempts to challenge gender norms and to promote women's empowerment in the liberated zones between 1976 and $1978 .{ }^{33}$

As Indonesia gained the upperhand, Beatriz, Tomás and Teresa reluctantly agree to come down from the mountains as part of the mass surrenders in 1979. They proceed to live in a simple hut in Bibileo, a village made up of a collection of similar 
huts arranged around a small field, guarded by an Indonesian military camp. The village 'was a prison,' as Beatriz's voice-over narration tells us, set up especially for those Timorese who had surrendered. A group of Indonesian soldiers under Captain Sumitro (Gaspar Sarmento) watch over them. Everyday life is heavily restricted, for example, soldiers stand guard over villagers bathing in the river.

The 1983 ceasefire between the Timorese resistance and the Indonesian army is a pivotal moment in the film. Beatriz falls pregnant with her first child during the ceasefire. Despite the ceasefire, Captain Sumitro and his superior, Major Prabowo, interrogate Tomás, whose father Celestino is a resistance leader, about the movements of resistance troops. ${ }^{34}$ Tomás is tortured and finally returns home, only to witness Sumitro's rape of Beatriz. The film suggests the rape was the army's provocation against the resistance fighters. Indeed, Tomás tells his father about the rape against which the resistance plans a retaliation. In the film, the shooting of several Indonesian soldiers during a flag-raising ceremony punctures the fearful atmosphere of the village. As Sumitro drones on and on during the ceremony about the importance of Indonesian nationalism, Timorese men, thought at first to have been Indonesian loyalists, open fire, killing several soldiers. Sumitro escapes, but the army conducted a number of operations afterward against the villagers, culminating in the shooting of unarmed men and boys on the riverbed.

The film provides a dramatic reenactment of the riverbed slaughter that forms part of the 1983 Krarás Massacre in the only known visual depiction of this event so far. In the lead up to it, the film shows, Indonesian soldiers come to the village to seek retribution for their dead comrades. Beatriz and Tomás flee from the village, but are separated from one another. Beatriz observes events from the riverbank, as soldiers order the village men to the dry riverbed, and once there, to sing a pro-independence 
song, Foho Ramelau (Mount Ramelau, East Timor's highest peak). While they sing, the soldiers mow them down with gunfire (a sequence of events that emerged over research with survivors of the massacre undertaken by scriptwriters, Luigi Acquisto and Irim Tolentino). Beatriz examines the corpses of the village men, but unable to find Tomás amongst the bodies, she remains convinced that he is still alive.

The army relocates the survivors of the massacre, women and girls, including Teresa, Beatriz and her son Celestino Jr. to a seaside village, Klalerek Mutin (a village also called Bibileo Baru, New Bibileo by the Indonesians). This village is depicted as dry, hot and flat with few opportunities to hide or engage in subterfuge. The women and girls grieve for their dead men and boys, left unburied on the riverbed, now far away. Despite having no seeds or farming implements and no men to farm the land, the women survive by collecting and selling salt, and over time, by breeding animals such as pigs and goats. As Aburto Guzman has written in relation to Colombian director Sergio Cabrera's film Golpe de Estadio, depictions of women's everyday life show 'the work and toil of peripheral nonurban living and the impact of violence on [their] livehood', showing 'the long-lasting ramifications of working people's loss during wars not of their making'.${ }^{35}$ The women do guard duty to ensure that no one escapes Klalerek Mutin and no Falintil soldier attacks the village; otherwise the Indonesian soldiers will kill some of the women as punishment.

Although the women are not combatants and armed conflict is not explicitly depicted on screen, the war against the Indonesian forces is never far away. Soldiers live in the village and Falintil guerrillas are in the nearby forest. Therefore, the women can never escape the conflict. When Sumitro tells Teresa to 'come to [his] hut tonight', she rejects his sexual advance by spitting on the ground in front of him. However, Beatriz urges her sister-in-law to carry out his instruction so the community 
could survive. In this tense exchange between them, they discuss the options open to the women:

Teresa: [Survive] for what? They shoot us like dogs. We're nothing to them. Beatriz: For every one they shoot, we'll grow ten. We'll grow an army. We'll fight and drive them out.

She tells Teresa that the women will bear children to the Falintil guerrillas nearby and the men in surrounding villages to strengthen the largely female community. Teresa does not agree with this strategy, "No, we're not whores." Beatriz does not only have Timorese men in mind. She tells Teresa, "You'll become Sumitro's wife. You've no choice.” Teresa still disagrees.

Teresa: I won't.

Beatriz: You have to. You can protect us. You can get information.

Beatriz forces her to acquiesce to Sumitro's demands, much to Teresa's anguish. As Tomás’ wife, Beatriz reminds Teresa that she now has authority over certain decisions in the family. In addition, by virtue of war, morality is suspended. As John Belton has described, the war movie (in which 'extreme expressions of love, hate, action, violence, and death can find representation') plunges 'its characters into a world of extremes where the slightest action (or even inaction) results in death—-their own or that of their comrades.' ${ }^{36}$ For the sake of the community's survival, Teresa must, and does, sacrifice herself. 
The family unit in this context, as the film shows, is not unproblematic and is not always a site of resistance, despite Beatriz's portrayal of child-bearing as a form of cultural survival and resistance. (In a voiceover narration, she tells that the presence of twenty-four children born in the village after one year stopped Indonesian soldiers from killing.) In a domestic scene, Sumitro, Teresa and their baby daughter, Kemala are shown as living together in a bamboo hut. They share a love for Kemala, despite the coercive element in their relationship. The use of symbolism, such as a deer tied to a stone that Sumitro has captured in the forest, symbolises Teresa's predicament. The family, therefore, the film suggests, is also a site of oppression and subjugation. Unconventional families and children borne out of forced sexual relations resulted from the political conflict.

The period following the 1999 UN ballot is depicted as bittersweet. In the lead-up to the ballot, Beatriz urges the women in Klalerek Mutin to vote, for a chance at independence and ukun rasik'an (self-determination). The film then uses archival footage to show the burning and destruction of Dili, in the aftermath of the 4 September announcement that the Timorese had rejected Indonesia's special autonomy package for East Timor. Sumitro and his men leave, taking his fifteen-yearold daughter, Kemala with him, as InterFET forces close in. Teresa tries to stop him. On the road, they argue about her identity, whether she is Indonesian or Timorese, and where she ought to be. Teresa concedes defeat, when Sumitro threatens to kill Kemala altogether with his pistol.

It was only after the ballot that many families began to piece together what happened to their loved ones during the occupation. At this point, the film begins to draw heavily on the 16th century case of Martin Guerre, a man who disappeared from his village in France one day, only to reappear years later. Like the long-lost Martin 
Guerre, a man purporting to be Beatriz's husband Tomás (José da Costa) appears in the village, when former resistance fighters trickle down from the bush where they had been hiding. Tomás seems familiar with the village's inhabitants, telling them that after surviving the Krarás massacre, he spent years fighting with Falintil.

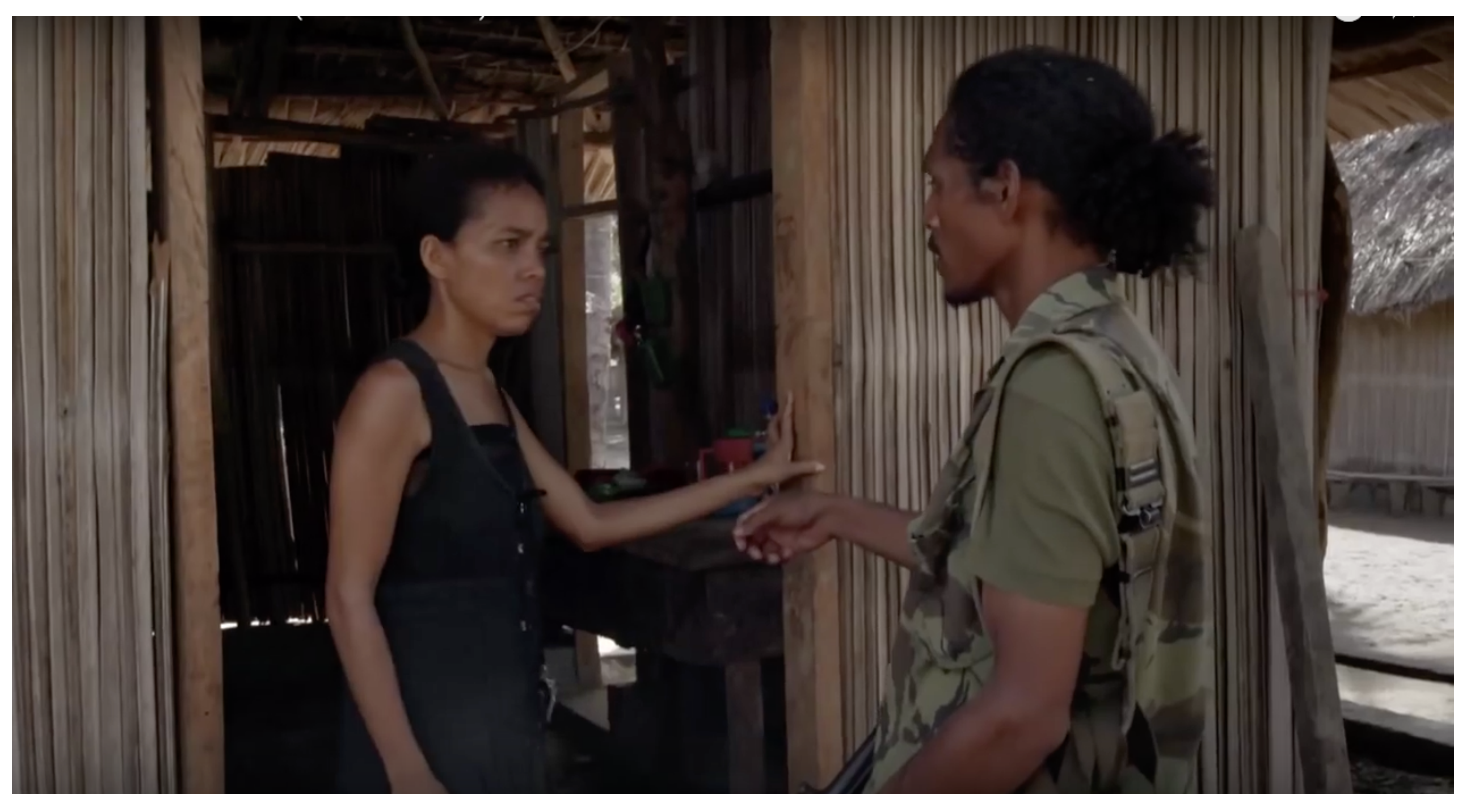

Image 2: Beatriz meets the man purporting to be her husband Tomás. From Beatriz's War, dir. Bety Reis and Luigi Acquisto. Screengrab.

The war has changed Tomás into a hardened soldier, no longer the gentle, timid man he was. The villagers, including Teresa, see his return as a positive omen, but Beatriz is suspicious. She uses the pretext that Teresa has held a ceremony, the doku bikan (turning of the plate) to signify his death, to hold him at bay and refuse him re-entry into her life. The Timorese custom of 'turning the plate' to face downwards allows closure after the death of a loved one by signifying that the deceased, their soul released, no longer eats at the family table.

Teresa's status as the 'wife' of an Indonesian soldier becomes the focus of a heated debate in the family, finally exposing the rifts, tensions and resentments created by the occupation. Tomás condemns Teresa as a traitor, for having had an 
Indonesian husband, when he sees the beautiful dresses hanging in her hut. Later, as the family sits by a campfire on the beach, Tomás asks for Beatriz's forgiveness for failing to run with her that day in Krarás. Beatriz replies that she has forgiven him, because ultimately the ceasefire in 1983 (and its breakdown) had little meaning. At this point, a bitter debate ensues between Teresa and Beatriz. Teresa argues that the ceasefire, if it held and was respected by both sides, could have made a difference to the course of all their lives. Their father, Celestino, shot by the Indonesians as part of the retaliatory operations, could still be alive. Beatriz maintains that the resistance's shooting of the Indonesian soldiers, done to avenge her honour after her rape, was the right course of action.

Beatriz: Your father was right to retaliate for what they did to me. At least we had some justice. A pity we didn't kill that pig (Sumitro).

Teresa: You didn't kill him. You forced him on me. You made me into a whore, made me bear a child that was then taken from me.

Beatriz: We needed to find a way to live.

Teresa: But you didn’t live like us. You remained apart from us. You remained true to what you believed. To Tomás.

Although the film depicts Beatriz as also having suffered a great deal emotionally, in Teresa's eyes Beatriz remained morally superior, being the wife who remained devoted to the memory of her lost husband. Teresa spoke of how her agency was diminished, in the service of a greater collective goal, that of surviving and resisting the Indonesian occupation using whatever flawed strategy was at hand. 


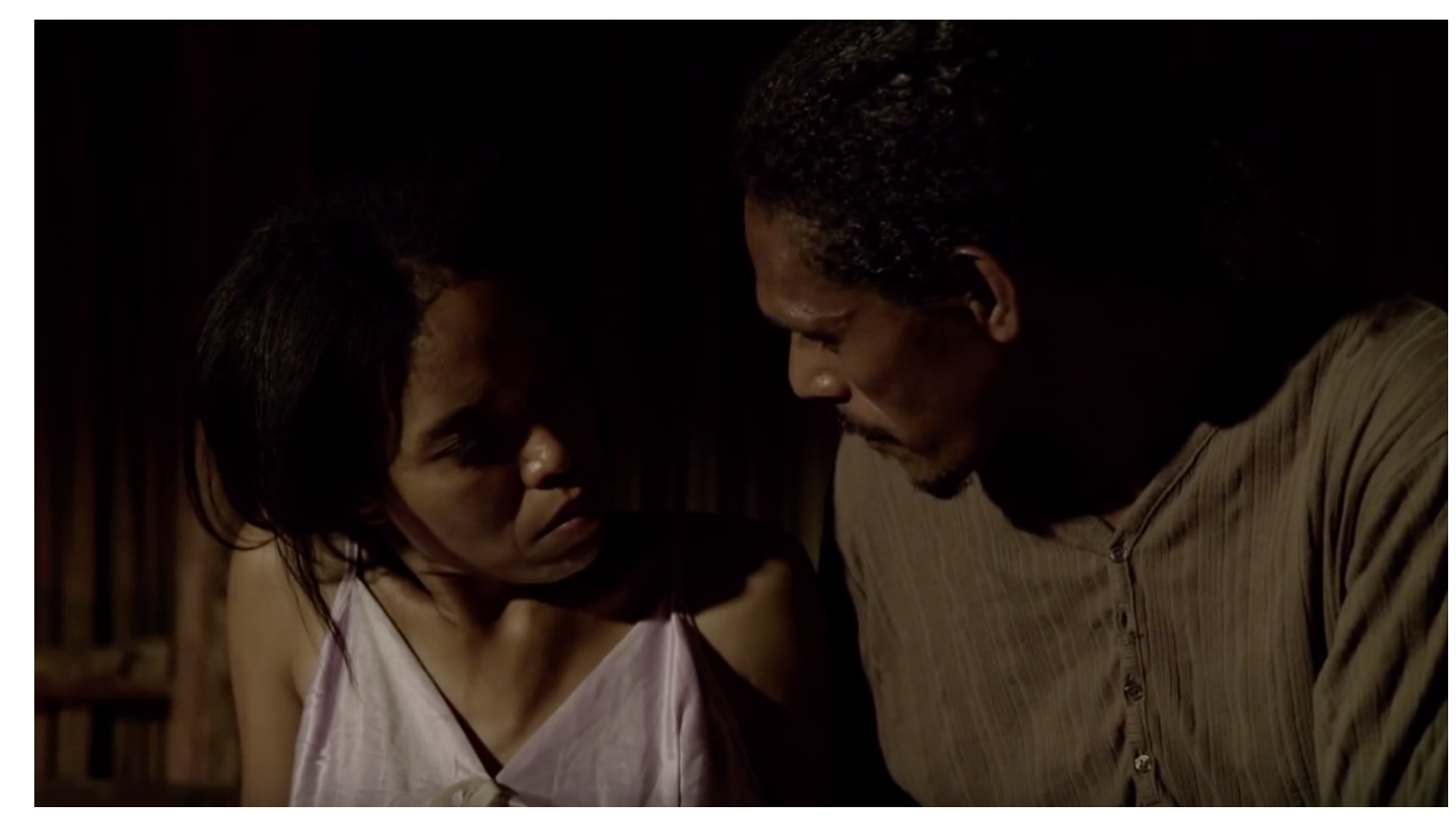

Image 3: An intimate moment between Beatriz and Tomás. From Beatriz's War, dir. Bety Reis and Luigi Acquisto. Screengrab.

The film ends with Tomás' imposture being discovered, as several eyewitnesses identify him as Pedro Cortes, a pro-Indonesia militiaman, who had participated in the murder of a group of clergy and nuns in Los Palos, in the eastern part of the country. These real-life killings, committed by the Tim Alfa militias, occurred on 25 September 1999. In the film, as his deeds are discovered, Tomás, or rather Pedro Cortes, is tied to a tree and left there, as rain falls and a deluge engulfs the village. Beatriz meets Pedro one last time, after he is handed over to UN peacekeeping forces, where she tells him, despite her own affection towards him, that he has betrayed her and violated her dignity, 'something not even the Indonesians did.' Though vowing never to forgive Cortes, Beatriz accepts the baby she has with him after some persuasion from Teresa, and names her Estela, after her mother.

\section{Receptions and 'rules of engagement'}


Thousands of people have seen Beatriz's War in public screenings throughout TimorLeste, including in the villages around Krarás, supported by a grant from the President's office to tour the film around the country. According to co-producer and lead actor, José Da Costa, the film allowed audiences in Maliana, in the west of the country, for example, to see images of the eastern part of the country and appreciate the suffering experienced there. ${ }^{37}$ During the making of the film and afterwards, Krarás villagers maintained, however, that there was not one massacre in September 1983 at the riverbed, but several, a claim that is of course historically accurate. In a reflection on her own thwarted attempts to observe the making of the film, Amy Rothschild has raised questions about the ownership of the Krarás story and the authority of foreign filmmakers to tell it. She objects in particular at one foreign filmmaker's attempt to keep the gaze of outsiders like her away from the film project (although she seems to underplay the involvement of an all-Timorese cast and a majority Timorese crew in the production). ${ }^{38}$

Internationally, the film has screened at cinemas and festivals and won awards such as for the Golden Peacock for Best Film at the 2014 International Film Festival of India. In Australia, one of the countries highlighted in the film as being complicit in supporting the Indonesian occupation and where some 9000 Timorese live, the film premiered at the 2013 Adelaide International Film Festival in South Australia. ${ }^{39}$ At the end of the film, a Timorese woman in the audience told the gathering, "It is my story, it happened to me." ${ }^{\prime 40}$ Many Timorese in the diaspora in countries such as Portugal and Australia were involved in activism for their homeland, having escaped from Indonesian rule. Clearly, the film resonated with one audience member that night in Adelaide. However, not all responses have been positive. 
In the following section of the paper, I analyse three of the criticisms raised in Indonesian film critic Windu Jusuf's review article about the film's depiction of history. ${ }^{41}$ The article summarises a panel discussion following one film showing in Jakarta, Indonesia in December 2014. I analyse these criticisms as an entry point into exploring how the film contributes to a historiophoty of Timorese society under Indonesian rule and a depiction of human emotions and relationships.

The history film's visual language and its depiction of those aspects that are hardest to do in the written word, such as emotions and landscapes, are precisely those that receive the most criticism from those quoted in Jusuf's article. One Indonesian critic, Hafiz Rancajale, at the Jakarta showing, argues that the film exoticizes the Timorese landscape. ${ }^{42}$ With land and landscape being so central to the resistance and the predominantly peasant population of Timor-Leste, it is no surprise that both feature heavily in the film and illustrate the spatial dimensions of the struggle. The film shows the importance of the landscape in waging a war. Both sides took advantage of the geographic terrain and features such as mountains, caves, forests and rivers in the fighting.

I argue that the film uses the landscape to evoke the changing fortunes of the characters, and landscape is therefore central to the film. In the opening scenes, the protagonists find an idyll in which to roam free, their leaders having just declared independence from Portugal. On their wedding day, Tomás and Beatriz run to the hills to play, talk, and gaze at the local red Timorese cattle from a distance. Men and boys hold a rowdy cockfight in the village square (albeit a sanitized version, without blades attached to the roosters' feet).

The hills (and in turn the Timorese ancestors who populate them) protect the young people from the foreign invaders who seek to tame the land and its people. As 
their circumstances change (and their control of the land slips away), so too does the landscape. Having surrendered and left the mountainside, the occupiers force the Timorese onto flat plains where they can be easily monitored. The pebbly, rocky riverbed in misty Krarás where the men are shot gives way again to the flat, dry, salty and sandy terrain of Klarerek Mutin where the sun shines harshly all day long. The protagonists' changing relationship to the land and the remaking of the landscape connect the viewer, like those who dwelled in Maliana, to the visual aspects of the country, as well as symbolising the decline in the protagonists' fortunes.

At this point, it is pertinent to discuss the film's 'look' to enable the reader to appreciate the visual (and auditory aspects) and filmic discourse of Beatriz's War. The filmmakers have used mainly natural lighting in locations that are vastly different visually and geographically. ${ }^{43}$ These sites include the hills and beaches on the outskirts of Dili, the dry and sundrenched seaside town of Liquiça, and the verdant landscape of the Krarás highlands with its misty and cloudy days. Small oil lamps and Petromax lanterns are used in night scenes to create alternately a sense of intimacy and a menacing sense of doom. Footage from beachside Tibar, near Dili, and Ulmera, near Liquiça is edited to form one composite scene of action taking place in the lowlands. Mountain scenes from Ainaro and Viqueque districts are similarly combined into one depiction of Kraras. The exterior of a church near Aileu in the central highlands, lamplight glowing in its windows, is then combined with the warmly lit interior of the Motael church in Dili where Beatriz and Teresa talk to Father Nicolau. Such combinations are not unusual in filmmaking, but have drawn some criticism from Timorese viewers, who are familiar with the locations, and puzzled by the combination of different places, with film being a relatively new medium there. ${ }^{44}$ 
The film recreates village scenes, such as the cockfight, and women collecting water and firewood and feeding the animals that roam free, including pigs, goats and chickens. Many scenes are shot inside simple huts of an architectural style that Timorese villagers continue to build. Such huts have bamboo and palm walls, a palm thatch roof and earthen floors. Visible also are everyday village objects, all of which continue to be used today, such as katana knives, woven baskets, tais textiles, floor mats and earthenware pots.

Accordingly, the soundscape of the film relates to these village scenes. The sounds of everyday 'women's work' range from the thwack-thwack of firewood being trimmed using katana knives and the women's chatter while washing clothes by the river or raking their saltpans. They rear animals for sale and food, so young shepherds chase their bleating goats down rockfaces and pigs grunt contentedly in response to Beatriz's special call to them at feeding time. Chickens peck and cluck incessantly, including around the prone body of Beatriz shortly after her rape, as if to symbolise their resilience and pursuit of survival. Depending on the scene location, the ambient sounds include the lapping waves of the sea and the quiet trickle of a village stream, as well as crowing roosters. Given the distressing subject matter of the film, the crying of women, children and babies also feature heavily in the soundscape.

The film's soundtrack consists of original music by Australian composer Jamie Saxe and music by Timorese musicians, including Osme Gonçalves and Felicia Maia, and contemporary renderings of folk songs. These tracks are variously haunting, or strident and lively, depending on the action in the film. The singing of the hymn, Foho Ramelau, based on survivors' recollections, just prior to the river shootings, easily frames the violence as an attack on East Timor's nationalist movement. The use of archival footage of the 1999 burning and looting of Dili, and 
independence hero, Xanana Gusmão's first address to the Timorese people, reminds the viewer that the fictional story is related to real events. The 'look' of the film and its soundscape enable viewers to engage with the imagery of Timor-Leste and the struggle for independence of this small half-island nation.

\section{Emotions and intimacy}

The film's depiction of personal relationships and intimacy on screen has attracted criticism, with one critic questioning if such topics belong in a war movie. Rancajale criticises the film as being excessively sentimental, and that the love story between Beatriz and Tomás reduces the film to barely more than a soap opera (sinetron). ${ }^{45}$ Yet film as a visual medium provides the opportunity of representing the innermost feelings and emotions of the characters, a speculative venture that is more likely to be dismissed in many academic history texts. Not only on screen but also in voiceover narration, we gain an insight into Beatriz's feelings and her views about those around her. The violence of the occupation altered the most basic of human relations. In focusing on love, morality, and shame and other emotions, Beatriz's War has opened up new ways of thinking about the occupation and its impact on the East Timorese. Such a possibility is perhaps also enabled by film's power in not only wanting 'to teach the lesson that history hurts; it wants you, the viewer, to experience the hurt (and pleasures) of the past,' as Rosenstone has argued. ${ }^{46}$

New ways of thinking about the occupation can also lead to discomfort, however. For example, the film has been criticised for its depiction of the intimate relationship between Sumitro, an Indonesian army officer and Teresa. Timorese activist, Maleve Guerra rejected the film's portrayal of their cohabitation. Yet Indonesian soldiers participating in military operations all over the country and in 
East Timor committed rape and took local women as long-term partners under coercive arrangements. ${ }^{47}$ Guerra preferred to highlight, however, that the Krarás massacre 'radicalised women and motivated them to become involved in armed resistance,' though women were only ever a minority of the armed resistance movement. Beatriz's War's portrayal of Timorese women's lives as bitter, at times morally compromised, and replete with ambiguities is difficult to accept for some Timorese in their desire to narrate an uncomplicated account of heroism.

\section{Conclusion}

By focusing on women's everyday experiences of conflict, Beatriz's War shows the moral ambiguities and compromises that arise in times of war and occupation. The film argues for social acknowledgement and greater understanding of the experiences of ordinary Timorese during the country's extremely brutal and violent past. It furthermore highlights how keeping culture alive and raising the next generation could well be strategies of resistance, however flawed as strategies these may be.

The film contributes to the historiophoty of the Indonesian occupation of East Timor between 1975 and 1999. Through the story of Beatriz and her family's plight over the course of the occupation, it has depicted the East Timorese landscape, scenery, atmosphere, emotions, and complex, yet undocumented events, such as massacres. In showing on screen the unfolding of rituals on marriage, birth, separation and death, as well as debates on changing gender roles and the place of traditional customs, we see how 'tradition' is constantly being adapted and shaped to changing times in East Timor. The film also circulates visual imagery, some of it necessarily speculative, of Timor-Leste's landscapes and rituals, as well as images of events during the occupation. Such speculative depictions include, for example, how 
massacres like Krarás may have been carried out, based on survivors' recollections. Ultimately, Beatriz's War forms part of a collective storytelling about Timor-Leste's traumatic history at a time when the East Timorese still feel acutely the need to tell and hear these stories as part of an exercise in collective memory and healing.

\section{Endnotes}

${ }^{1}$ A Guerra Da Beatriz (Beatriz’ War), directed by Bety Reis and Luigi Acquisto (Dili: Dili Film Works, 2013).

${ }^{2}$ In this article, I use the term 'East Timor' to refer to the period before 2002. For population data, see '2015 Timor-Leste Population and Housing Census - Data Sheet' http://www.statistics.gov.tl/wp-content/uploads/2016/11/Wall-Chart-PosterLandscape-Final-English-rev.pdf.

${ }^{3}$ Lia Kent, 'After the Truth Commission: Gender and Citizenship in Timor-Leste', Human Rights Review 17, No. 1, (2016), p. 67.

${ }^{4}$ See for example John G. Taylor, East Timor: The Price of Freedom (New York: Zed Books, 1999); Clinton Fernandes, The Independence of East Timor, MultiDimensional Perspectives: Occupation, Resistance, and International Political Activism (Portland, Oregon: Sussex Academic Press, 2011); James Dunn, East Timor: A Rough Passage to Independence, (Double Bay, NSW: Longueville Books, 2003); and Michael Leach, Nation-Building and National Identity in Timor-Leste (Abingdon, Oxon: Routledge, 2016). 
${ }^{5}$ Loney, “This is Me', p. 3.

${ }^{6}$ Irena Cristalis and Catherine Scott, Independent Women: The Story of Women's Activism in East Timor (London: Catholic Institute for International Relations, 2005);

M.D.F. Alves, L.S. Abrantes, and F.B. Reis, Hakerek Ho Ran (Dili: Office for the Promotion of Equality, 2003); Jude Conway, Step by Step: Women of East Timor, Stories of Resistance and Survival (Darwin, NT: Charles Darwin University Press, 2009).

${ }^{7}$ Kent, 'After the Truth Commission', p. 63.

${ }^{8}$ William L. Hewitt and Jonathan C. Friedman, 'Introduction', in William L.

Hewitt and Jonathan C. Friedman (eds), The History of Genocide in Cinema:

Atrocities on Screen (New York: I.B. Tauris, 2017), p. 8.

${ }^{9}$ Robert A. Rosenstone, History on Film/Film on History (Abingdon, Oxon:

Routledge, 2014), p. 8 and Hayden White, 'Historiography and Historiophoty', The American Historical Review 93, No. 5, 1988, p. 1193.

${ }^{10}$ White, 'Historiography and Historiophoty', p.1193.

${ }^{11}$ Peter Brooks, The Melodramatic Imagination: Balzac, Henry James, Melodrama, and the Mode of Excess (New York: Columbia University Press, 1985), p. 12.

${ }^{12}$ Nick Browne, 'Society and Subjectivity on the Political Economy of Chinese Melodrama', in Nick Browne, et al. (eds), New Chinese Cinemas: Forms, Identities, Politics (Cambridge; New York: Cambridge University Press, 1994), p. 43.

${ }^{13}$ Brown, 'Society and Subjectivity on the Political Economy of Chinese Melodrama', p. 53.

${ }^{14}$ Clinton Fernandes, “"This Time We Are Going to Hit Them Without Mercy”: Indonesian Operations and East Timor's First Feature Film' in William Hewitt \& 
Jonathan Friedman, (eds), History of Genocide in Cinema: Atrocities on Screen (New York: I.B. Tauris. 2017), pp. 182-95.

${ }^{15}$ David Callahan, 'East Timor's First Film: Beatriz's War, History and Remediation', Studies in Australasian Cinema 10, No. 3, (2006), p. 303.

${ }^{16}$ Helen Hill, Stirrings of Nationalism in East Timor: Fretilin 1974-1978, The Origins, Ideologies and Strategies of a Nationalist Movement (Otford, NSW: Otford Press, 2002).

${ }^{17}$ Other parties were Apodeti, Klibur Oan Timor Assuwain (KOTA) and Partido Trabalhista, the Workers' Party. On the period just prior to the invasion, see Dionisio Babo Soares, 'Political Developments Leading Up to the Referendum', in James J. Fox and Dionisio Babo Soares (eds.), Out of the Ashes: Destruction and Reconstruction of East Timor (Bathurst: Crawford House Publishing, 2000), p. 54.

${ }^{18}$ Gerry Van Klinken, 'Prabowo and Human Rights', Inside Indonesia 116, (2014).

${ }^{19}$ Loney, "This is Me", p. 3.

${ }^{20}$ Lia Kent, 'Narratives of Suffering and Endurance: Coercive Sexual

Relationships, Truth Commissions and Possibilities for Gender Justice in TimorLeste', International Journal of Transitional Justice, Vol. 8, No. 2, 2014, pp. 289313. On the Indonesian authorities' practice of removing children from their families in East Timor, see Helene Van Klinken, Making Them Indonesians: Child Transfers out of East Timor (Clayton, Vic: Monash University Publishing, 2011).

${ }^{21}$ See for example Miranda E. Sissons, From One Day to Another: Violations of Women's Reproductive and Sexual Rights in East Timor (Melbourne: East Timor Human Rights Centre, 1997) and Rebecca Winter, Buibere: Voice of East Timorese Women, Vol. 1 (Darwin, NT: East Timor International Support Center, 1999). 
${ }^{22}$ Hannah Jane Loney, 'In Women’s Words: A New History of Violence and Everyday Life During the Indonesian Occupation of East Timor (1975-1999)', PhD Thesis, School of Historical and Philosophical Studies, The University of Melbourne, 2016.

${ }^{23}$ Kent, 'After the Truth Commission', p. 67, Loney, 'In Women's Words,' and Nuno Rodrigues Tchailoro, 'Everyday Resistance and Its Relation with Independence Movements', Presented at the Timor-Leste Studies Association Conference (Dili, 29-30 June 2017).

${ }^{24}$ Philip Kitley, Television, Nation and Culture in Indonesia (Athens: Ohio University Press, 2000), pp. 217-224.

${ }^{25}$ Angie Bexley, 'Independence and Indigenous Film: The Framing of Timor-Leste', in May Adadol Ingawanij and Benjamin McKay (eds), Glimpses of Freedom:

Independent Cinema in Southeast Asia (Ithaca: Cornell Southeast Asia Program Publications, 2012), 140-1.

${ }^{26}$ Max Stahl, Cold Blood: The Massacre of East Timor, (United Kingdom: Yorkshire Television for ITV, 1992); David Munro, Death of a Nation: The Timor Conspiracy, (United Kingdom: Central Independent Television, 1994).

27 These films include, for example, James Leong and Lynn Lee, Passabe, (Singapore: Lianain Films, 2004); Andrew Sully, Anatomy of a Massacre, (Australia: Cordell Jigsaw Production, 2010); Rahung Nasution, Rock and Roll with Jakarta, (Indonesia and Timor-Leste: SAHE Media Popular and Off Stream Production, 2005).

${ }^{28}$ Beatriz's War Press Kit, http://www.aguerradabeatriz.com/wpcontent/uploads/2014/06/Beatrizs-War-Press-Kit-June-14-Large.pdf ${ }^{29}$ Jose Da Costa, Personal communication, 2 April 2017. 
${ }^{30}$ On the practice of barlaque, see Kelly Silva, 'Marriage Prestations, Gift Making, and Identity in Urban East Timor', Oceania 88, No. 1 (2018), pp. 127-47.

${ }^{31}$ Leach, Nation-Building and National Identity in Timor-Leste, p. 70.

${ }^{32}$ On the undermining of social fabric of society through gender-based and sexual violence, see Lia Kent, 'Narratives of Suffering and Endurance', p. 298.

${ }^{33}$ Leach, Nation-Building and National Identity in Timor-Leste, p. 70.

${ }^{34}$ Based on Prabowo Sugianto, Indonesian former Special Forces commander, who had fought in East Timor in the early 1980s, and was implicated in human rights abuses, specifically the kidnapping of pro-democracy activists in 1998. Prabowo heads the Great Indonesia Movement Party (Gerindra) and ran as presidential candidate in 2014. See Van Klinken, 'Prabowo and Human Rights'. ${ }^{35}$ Claudia Aburto Guzman, 'A People's Humour as an Aesthetic Stratagem in Golpe de Estadio', Karen A. Ritzenhoff and Jakub Kazecki (eds.), Heroism and Gender in War Films, (New York: Palgrave McMillan, 2014), p. 104.

${ }^{36}$ John Belton, American Cinema/American Culture (New York: McGraw-Hill, 2013), pp. 195-6.

37 Jose Da Costa, Personal communication, 2 April 2017.

${ }^{38}$ Amy Rothschild, 'Malae Melee: A Failed Attempt to Observe the Making of Timor-Leste's First Feature Film', Maj Nygaard-Christensen and Angie Bexley (eds.), Fieldwork in Timor-Leste: Understanding Social Change Through Practice (Copenhagen: NIAS Press, 2017), p. 234.

${ }^{39}$ Amanda Wise, Exile and Return Among the East Timorese (Philadelphia, Pa.: University of Pennsylvania Press, 2006), p. 47.

${ }^{40}$ Eddie Cockrell, 'Beatriz's War Review', SBS, 29 October 2013, http://www.sbs.com.au/movies/review/beatrizs-war-review. 
${ }^{41}$ Windu Jusuf, ‘Menjadi Indonesia Pasca Beatriz's War', Cinema Poetica, no. 21 January 2015, http://cinemapoetica.com/menjadi-indonesia-pasca-beatrizs-war.

42 Jusuf, 'Menjadi Indonesia Pasca Beatriz's War'.

${ }^{43}$ Insights about location, lighting and editing provided in Jose Da Costa, personal communication, 2 April 2017.

${ }^{44}$ Jose Da Costa, personal communication, 2 April 2017.

45 Jusuf, 'Menjadi Indonesia Pasca Beatriz's War'.

${ }^{46}$ Rosenstone, History on Film, p.18.

${ }^{47}$ See for example Vannessa Hearman, Unmarked Graves: Death and Survival in the Anti-Communist Violence in East Java, Indonesia, (Singapore: NUS Press), (in press), pp. 180-1 on soldiers taking local women as 'wives' following a military operation against communists in South Blitar. 